\title{
The Central European drought of 1947: causes and consequences, with particular reference to the Czech Lands
}

\author{
Rudolf Brázdil ${ }^{1,2, *}$, Pavel Raška ${ }^{3}$, Miroslav Trnka ${ }^{2,4}$, Pavel Zahradníček ${ }^{2,5}$, \\ Hubert Valášek ${ }^{1,6}$, Petr Dobrovolný ${ }^{1,2}$, Ladislava Rezníčková ${ }^{1,2}$, Pavel Treml ${ }^{7}$, \\ Zdenĕk Stachoň ${ }^{1}$
}

\author{
${ }^{1}$ Institute of Geography, Masaryk University, Kotlářská 2, 61137 Brno, Czech Republic \\ ${ }^{2}$ Global Change Research Institute, Czech Academy of Sciences, Bělidla 986/4a, 60300 Brno, Czech Republic \\ ${ }^{3}$ Department of Geography, J. E. Purkyně University, České mládeže 8, 40096 Ústí nad Labem, Czech Republic \\ ${ }^{4}$ Department of Agrosystems and Bioclimatology, Mendel University in Brno, Zemědělská 1, 61300 Brno, Czech Republic \\ ${ }^{5}$ Czech Hydrometeorological Institute, Brno Regional Office, Kroftova 43, 61667 Brno, Czech Republic \\ ${ }^{6}$ Moravian Land Archives, Palackého nám. 1, 62500 Brno, Czech Republic \\ ${ }^{7}$ T. G. Masaryk Water Research Institute, Podbabská 30, 16062 Praha 6, Czech Republic
}

\begin{abstract}
A drought of exceptional severity took place in Central Europe in 1947, with marked socio-economic consequences and far-reaching political responses in the Czech Lands. A rich body of meteorological observations from the Czech Lands is drawn upon to construct a comprehensive picture of the various direct and indirect factors that led to this extreme event and to describe its impacts across a range of spatiotemporal scales. In terms of the Czech Lands in their entirety and the full 1804-2014 period of instrumental measurements, the 1947 drought, which lasted from April to October, may be expressed as very low monthly values of Standardised Precipitation Evapotranspiration Index for 1 month (SPEI-1), Standardised Precipitation Index for 1 month (SPI-1), and Palmer's Z-index. Independent evidence from mean monthly patterns of sealevel pressure suggests it originated in an anticyclone over Central Europe and ridges of high pressure extending over the area. Duration and deficiency volumes recorded at selected Czech hydrological stations indicate that the 1947 event was one of the 3 most important hydrologic drought episodes since the late 1880s. Severe agricultural drought was reflected in a low to extremely bad harvest of cereals and other agricultural crops. A critical lack of cereals was remedied by 'brotherly help', i.e. relief shipments from the Soviet Union given for reasons that were far more political than altruistic. The whole process received considerable attention in the national media, influencing public opinion for decades. It also led to various administrative responses and decisions at local, regional and even state levels. This study demonstrates that the 1947 drought was a significant climatic anomaly of great spatial extent, and with wide-ranging socio-economic consequences.
\end{abstract}

KEY WORDS: 1947 drought · Meteorological drought · Hydrological drought · Agricultural drought $\cdot$ Drought impact $\cdot$ Socio-economic responses $\cdot$ Czech Lands

\section{INTRODUCTION}

Drought, primarily originating out of deficiency in precipitation totals compared with mean patterns

\footnotetext{
${ }^{*}$ Corresponding author: brazdil@sci.muni.cz
}

over a given area (meteorological drought), differs from other meteorological or hydrological extremes in its slow onset. However, delayed impacts and consequences for water management (hydrological and

() The authors 2016. Open Access under Creative Commons by Attribution Licence. Use, distribution and reproduction are unrestricted. Authors and original publication must be credited. 
underground water droughts), agriculture (agricultural drought) and other fields (e.g. forestry) may have dramatic socio-economic consequences, including famine, epidemics, socio-political unrest and human migration (Heim 2002, Mishra \& Singh 2010). The recent drought episodes in Russia in 2010 (Trenberth \& Fasullo 2012), USA in 2011-2012 (Hoerling et al. 2014), China in 2013 and Brazil in 2014 were, for each particular year, among the 10 natural disasters worldwide with the highest recorded damage; the losses arising out of them and economic consequences were comparable with those of earthquakes and tropical cyclones (Munich Re 2015).

On a more regional scale, that of Central Europe and particularly of the Czech Lands (now the Czech Republic), drought is comparable with flood. These are the 2 most disastrous natural events that affect this region. This has recently been reflected, in the light of experience of the 2015 drought and other events from previous years, in the Water-Drought Commission report (Czech Government Resolution no. 620/2015) commissioned jointly by the Czech Ministry of Agriculture and the Czech Ministry of the Environment. The potential impact of drought on agriculture, forestry and water resources in the Czech Republic has recently been summarised by Brázdil \& Trnka (2015).

Despite the fact that intense droughts have occurred in the Czech Lands relatively frequently at least as far back as $\sim 500 \mathrm{yr}$, in the instrumental as well as in pre-instrumental periods (Brázdil et al. 2009, 2013, Trnka et al. 2009, Brázdil \& Trnka 2015), the 1947 episode remains one of the most remarkable. Various drought indices lead it to be categorised as either the most severe - or at least among the most severe-drought events in Czech history. Hardly surprisingly, responses to it included a large number of contributions to the Czech Meteorological Journal (Meteorologické zprávy), in which later droughts, largely from the 1950s, were always compared with that of 1947, and this episode has served as a benchmark for more than 2 generations of Czech climatologists. Moreover, the event stimulated further activities directed at mitigating potential damage from future drought events by means of irrigation, creation of windbreaks, construction of ponds, etc.; particularly in the province of South Moravia which, together with the Polabská nížina Lowlands (for local names and places in the Czech Republic see Fig. 1), constitutes one of the most important agricultural regions in the Czech Republic.

Because the 1947 drought occurred when the country was renewing itself, both logistically and politically, after the rigours of the Second World War, reactions in agriculture, water management, forestry and other sectors were more marked and longer lasting than might have been the case in a more stable economy. In particular, failure of the harvest at a time of very low reserves provoked a number of responses at various levels of the state administration, all de-

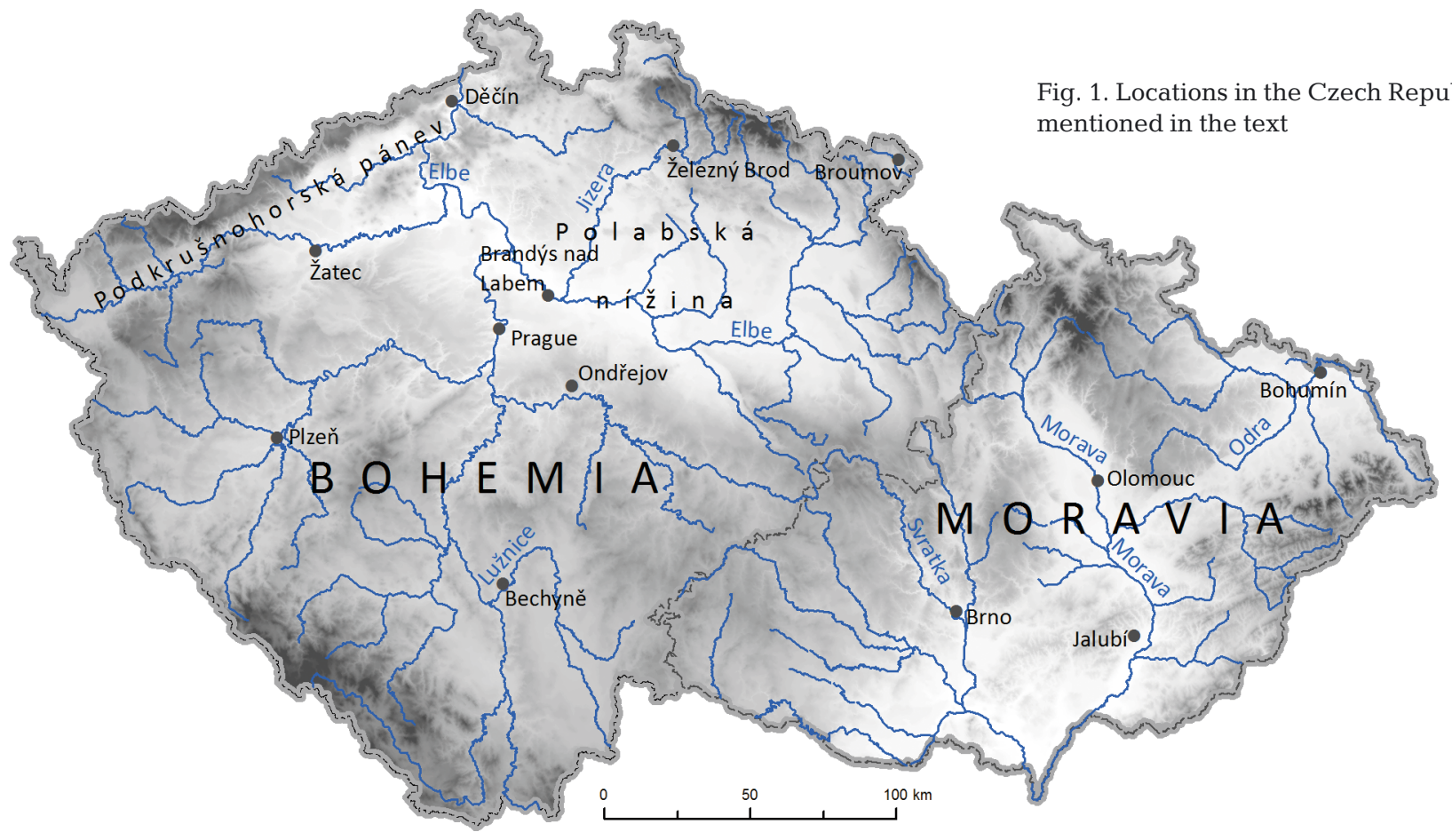


signed to mitigate negative impacts. The sheer magnitude of this event means that approaches and responses to the 1947 drought are of great informational value in reducing the future impacts of natural disasters. This holds especially true of the first decade of the 21st century, when several authors analysed social responses to historic disaster events with the aim of utilising society's past experiences to address current disaster risks (Poliwoda 2007, Schenk 2007, Pfister 2009). Learning from past disasters is considered to increase societal resilience to them (Voss \&Wagner 2010, Raška \& Brázdil 2015). According to Juneja \& Mauelshagen (2007), the main issues relevant to historical disaster research include the level of success with which past societies have faced disasters, the ways of interpreting past disasters, and processes of learning from disasters and passing on lessons of the experience to subsequent generations.

The present paper provides a comprehensive analysis of the 1947 drought episode in the Czech Lands, with particular attention to its physical nature, socioeconomic and political impacts and responses to it.

\section{DATA AND METHODS}

\subsection{Meteorological data}

Homogenised series of the monthly precipitation totals from the 787 stations of the Czech Hydrometeorological Institute (CHMI) were used to calculate April-October totals for 1961-1990 (Štepánek et al. 2011, 2013), providing a reference period and constructing a territorial distribution over the Czech Lands by means of orographic interpolation with universal linear kriging (Šercl \& Lett 2002). The same approach was applied to the 398 stations that recorded April-October 1947 totals. Comparison of the 2 maps (grids) enabled a geographical distribution of percentage portions of the 1947 totals with respect to the 1961-1990 period (see Fig. 4a). Similarly, N-year return periods for the April-October 1947 totals were calculated in the light of Gaussian distribution with respect to the 1961-2014 period (see Fig. 4b). Further, 4 stations were selected to represent the annual course of daily air temperature and precipitation: Žatec and Ondřejov in Bohemia (western part of the Czech Lands), Brno and Olomouc in Moravia (eastern part of the Czech Lands). Variations in mean daily temperatures at these stations in 1947 were expressed as deviations from the mean variations of the 1961-1990 reference period. Daily precipitation totals in 1947 were expressed as a cumulative curve compared with those of the 1961-1990 reference period (see Fig. 3).

This study also employs series of mean monthly Czech temperatures, calculated from 10 stations for 1800-2014, and mean monthly Czech precipitation totals calculated from 14 stations for 1804-2014 (Brázdil et al. 2012, extended for 2011-2014). From these 2 series, SPI-1, the Standardised Precipitation Index for one month (McKee et al. 1993), SPEI-1, the Standardised Precipitation Evapotranspiration Index for one month (Vicente-Serrano et al. 2010) and Zindex (Palmer 1965) were calculated for evaluation of droughts in the Czech Lands at a monthly level. The SPI, calculated from monthly precipitation totals, may be interpreted as the number of standard deviations by which an observed anomaly deviates from the long-term mean. The SPEI is similar to SPI, but rather than concentrating on precipitation alone, it is based on monthly differences between precipitation and potential evapotranspiration. It may therefore indicate anomalies in climatological water balance. The Z-index serves mainly to express anomalies in soil moisture, given as deviation of precipitation from climatological optimum in a given month. Compared to the more frequently used Palmer Drought Severity Index (PDSI), it represents only the current state of water balance without reference to antecedent soil moisture status.

General meteorological patterns are indicated in terms of annual variation in mean monthly Czech temperature and precipitation (expressed as deviations from the 1961-1990 mean in ${ }^{\circ} \mathrm{C}$ or \%), complemented by annual variations in SPI-1, SPEI-1 and $Z$-index (see Fig. 2). Drought indices were then evaluated in the long-term context for the 1805-2014 period.

Synoptic conditions in the driest months of 1947 (May, August, September, October) were analysed on the basis of monthly maps of mean sea level pressure (SLP), employing the HadSLP2r database (Allan \& Ansell 2006) and expressed for a section from the Atlantic-European area. However, it should be borne in mind that such SLP fields are the results of monthly averaging of daily synoptic situations that could correspond to quite different features in individual SLP fields. In addition, the frequency of synoptic types in any given month in terms of CHMI classification (Brádka et al. 1961) was compared with mean frequency in the 1961-1990 reference period. For the Czech Lands, Brádka (1972) indicated that precipitation occurs more frequently and in much higher amounts during cyclonic synoptic situations compared with anticyclonic types. 


\subsection{Hydrological data}

Figures from the Děčín station on the River Elbe, which drains most of Bohemia, were used for analysis of hydrological drought. Deficiency volumes, i.e. the cumulative volumes of water absent from threshold discharge $Q_{330}$ (i.e. the discharge achieved as a mean for 330 days of the year) were calculated from daily discharges in the 1888-2010 period. Because deficiency volume depends on the discharge value for a given river, this is standardised by dividing deficiency volume by the threshold discharge $Q_{330}$. Deficiency volume may also be expressed as a multiple of mean annual missing water with respect to $Q_{330}$ (for more information on this method, see e.g. Hisdal \& Tallaksen 2000, Tallaksen \& van Lanen 2004). Six further CHMI stations were used for comparison with the Děčín-Elbe station: Brandýs nad Labem-Elbe (1911-2005), Železný Brod-Jizera (1912-2009), Bechynĕ-Lužnice (1911-2009), Olomouc-Morava (1921-2009), Bohumín-Odra (1920-2010) and BrnoSvratka (1923-2009). These are used to characterise the order of the 1947 drought within series in Table 1 (Brázdil \& Trnka 2015).

For spatial analysis of the 1947 hydrological drought, Vlnas et al. (2010) calculated standardised deficiency volumes and duration of hydrological drought with respect to annual discharge $Q_{95}$ (i.e. $95 \%$ of mean annual discharge) from series of monthly discharges at 118 hydrological stations in the Czech Lands and expressed them as a map. From this, a simplified map was constructed for the purposes of the present study, demonstrating the main features of the 1947 drought (see Fig. 7).

\subsection{Other data}

The variety of documentary data sources that enable reconstruction of the social impacts of natural disasters, and responses to them, is broad, but thorough critical analyses are required with respect to their credibility and reliability (Stanford 1986, Raška et al. 2014). The data sources used in this study are listed in the Appendix. Four major types of data are used:

(1) Official country-scale sources. These take the form of parliamentary records kept in the digital repository of the Czech Parliament (Archival Source
4 [AS4] in the Appendix; www.psp.cz/eknih/index. $\mathrm{htm}$ ) and include stenographic records of requests for guidance and action from regional representatives as well as proposals for legislation and the reports of committees that responded to them. The stenographic records are particularly important since they provide detailed information of the impacts of drought at local and regional scales. However, these records must be interpreted in the context of the political and ideological positions of the representatives generating them.

(2) Official regional sources. The official regional sources, largely consisting of the records of National Land Committees, are available from land archives and provide detailed reports concerning regional impacts of a given drought episode and subsequent mitigation measures.

(3) The media. Rudé právo (AS6), the leading communist daily newspaper, was a major nation-wide source of public information in this period. Although the style and contents of its reporting are often constrained by an agenda dictated by the political aims of the Communist Party (see McCombs \& Shaw 1972), this newspaper provides fundamental information about the spatial extent of drought impact by reporting from a large number of localities and regions.

(4) Regional sources. Keeping local and village chronicles has a long tradition in the Czech Lands, and these often serve to complement the picture of the social impacts of an extreme event by adding qualitative narrative data.

The economic and social impacts of the drought, and consequent mitigation efforts, were reconstructed from documentary sources of a number of types. First, agricultural losses are calculated from annual yield series of main agricultural crops at national level (no data for district level exists). Supplementary 
parliamentary data on regional agricultural losses were extracted and aggregated for district level and represented as percentage decreases in production compared with 1946, and/or as total financial loss. Finally, the reconstructed territorial distribution of drought impacts was completed with data from national newspapers. Parliamentary records provided a chronology for the drought and other related events (mainly hailstorms, pest outbreaks and disease epidemiology) that contributed to total agricultural and financial losses in the regions. The chronology was supplemented with data referring to mitigation efforts, both as financial subsidies and acts of parliament. Such mitigation measures were extracted from documentary data and divided into specific groups according to their territorial scope and function.

\section{RESULTS}

\subsection{Meteorological drought and its synoptic causes}

Based on 3 drought indices (SPI-1, SPEI-1 and Zindex), the meteorological drought of 1947 in the Czech Lands had already started in winter months, despite a high precipitation total in February (calculations of all 3 indices take snow into account, meaning that high precipitation in drought indicies occurs when the snow melts, in the first month with air temperature $>0^{\circ} \mathrm{C}$ - here March). The next dry period started in April and continued all the way to October, with above-normal temperatures from April to September, the latter being the month with the highest positive deviation (Fig. 2). The reduction in precipitation was at its most pronounced in May and August-October, less so in June, while the July total achieved the 1961-1990 mean. In terms of annual variation, the drought culminated in September.

This picture may be further enhanced by the annual variation of mean daily temperatures and cumulative precipitation totals in comparison with the 1961-1990 means for the 4 stations representing western Bohemia (Žatec), central Bohemia (Ondřejov), southern Moravia (Brno) and central Moravia (Olomouc) (Fig. 3). A very cold period for JanuaryMarch appears in daily temperatures, while positive deviations started to prevail from April onwards until around the end of 1947. High temperatures were also accompanied by heat waves. For example, $40 \mathrm{~d}$ of annual heat wave duration and $46.9^{\circ} \mathrm{C}$ of annual cumulative daily maximum temperature in excess of
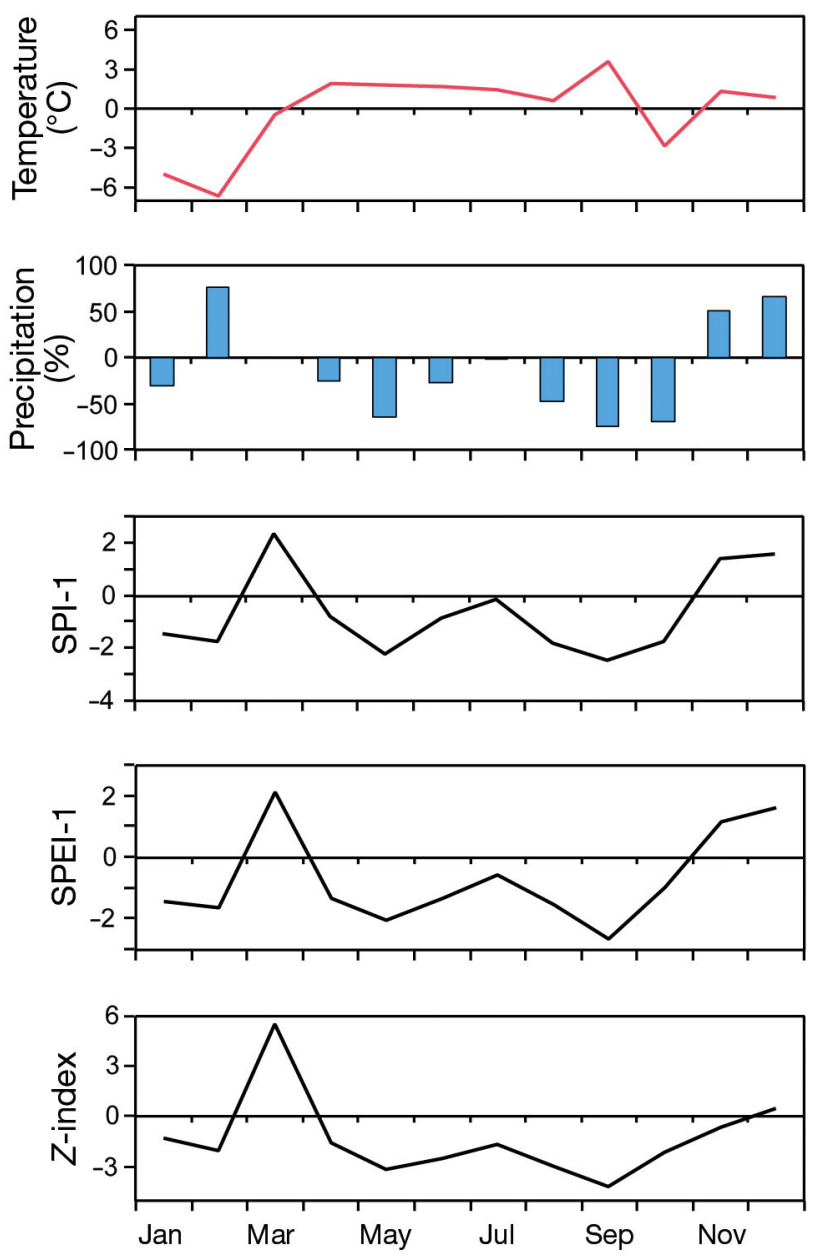

Fig. 2. Annual variation of monthly air temperature, precipitation, Standardised Precipitation Index for one month (SPI1), Standardised Precipitation Evapotranspiration Index for one month (SPEI-1) and Palmer's Z-index in the Czech Lands in 1947. Temperature and precipitation are expressed as deviations with respect to the 1961-1990 reference period

$30^{\circ} \mathrm{C}$ in the heat waves during 1947 , ranking second only to the year 1994 at the Prague-Klementinum station in the 1901-1997 period (Kyselý 2002). A nearly standard development of precipitation (i.e. around the mean totals) from the beginning of 1947 was interrupted in April, after which the precipitation deficit grew until October; in the following 2 mo the rate of deficit decreased slightly. The highest precipitation deficits, occurring in summer and autumn, reached around 150 to $200 \mathrm{~mm}$ over the Czech Lands as a whole, but were much greater in central Bohemia (Ondřejov).

With respect to the 1961-1990 reference period, the character of the territorial distribution of AprilOctober precipitation totals in 1947 is erratic (Fig. 4a). Central Bohemia was especially dry, with a 

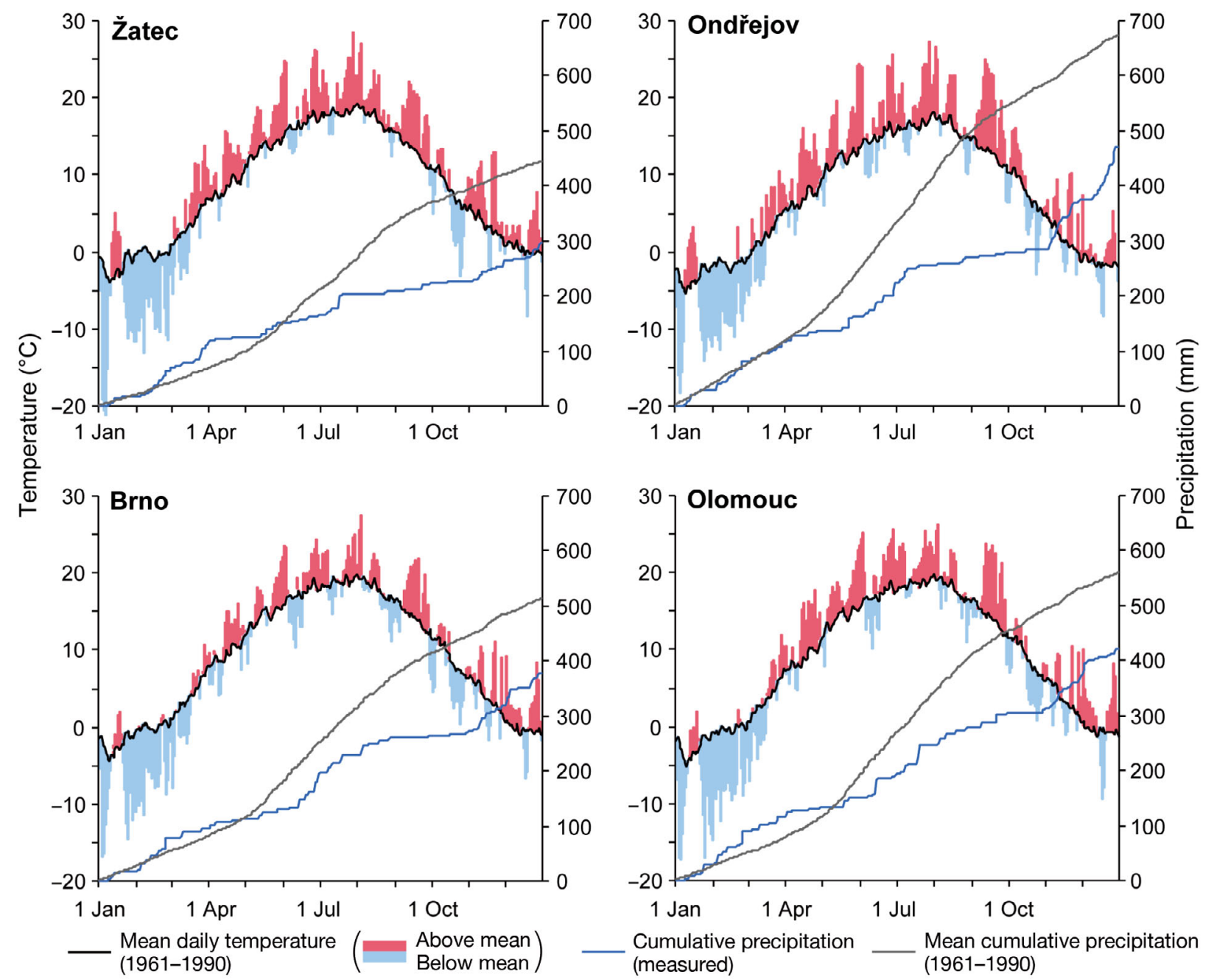

Fig. 3. Variations in mean daily temperatures and precipitation totals for the Žatec, Ondřejov, Brno and Olomouc stations in 1947: mean daily temperatures for 1961-1990 (black line); measured mean daily temperatures (red bars: above mean; blue bars: below mean); mean cumulative precipitation for 1961-1990 (grey line); measured cumulative precipitation (blue line)

belt of low precipitation extending to the Podkrušnohorská pánev Basin and 2 irregular belts extending from southeast to northwest in Moravia. More than two-thirds of the territory of the Czech Lands recorded precipitation totals of between 40 and $60 \%$ of the 1961-1990 mean (with values of 40.1 to $50.0 \%$ and 50.1 to $60.0 \%$ in 30 and $38 \%$ of the territory, respectively). Precipitation between 60.1 and $70.0 \%$ of the reference mean occurred over $18 \%$ of Czech territory, while precipitation over $7 \%$ of the Czech territory was between 30.1 and $40.0 \%$ of the reference mean. The low April-October precipitation totals correspond to a $100 \mathrm{yr}$ return period, longer over the greatest part of the Czech Lands (Fig. 4b). Lower return periods occurred particularly in southern Bohemia, with an extension to Plzeň, in northern Bohemia, and in north-eastern Moravia.
Synoptic reasons may be found for the very low monthly totals. In May 1947, the Czech Lands were under the influence of high pressure extending from the North Atlantic and Scandinavia over the Baltic Sea from the northwest to the southeast (Fig. 5). Anticyclonic synoptic types, according to CHMI classification (Brádka et al. 1961), occurred on 17 May days (i.e. 8 days more than in the 1961-1990 reference period). Low precipitation in August and September was associated with a ridge of high pressure extending from the Azores High to Central Europe. While in August its axis was directed towards the British Isles, in September it ran towards the northern Black Sea (Fig. 5). In August the Czech Lands were under the dominant influence of a northeasterly airflow for 25 days (cyclonic synoptic types: 15 days; anticyclonic: 10 days). Anticyclonic types made up 18 September 

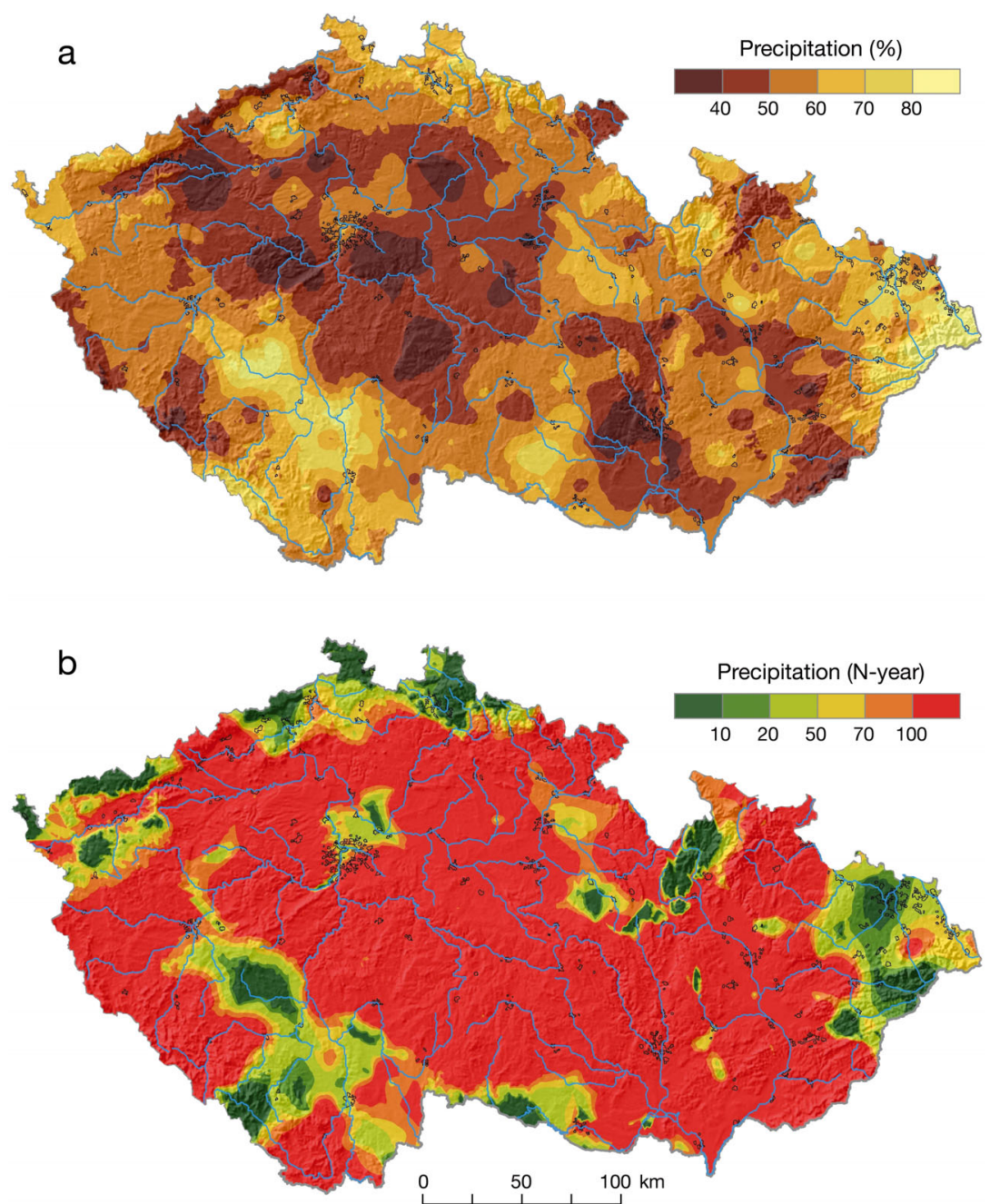

Fig. 4. Territorial distribution of April-October 1947 precipitation totals in the Czech Lands: (a) percentage of mean precipitation for the 1961-1990 reference period; (b) N-year return period of the 1947 drought event. Urban areas represented with black borders

days, i.e. 6 days more than in the 1961-1990 reference period. In October, the greater part of Europe was under the influence of high pressure with an isolated anticyclone extending from Central Europe to the Black Sea (Fig. 5). Anticyclonic synoptic types occurred in the Czech Lands on 25 October days (i.e. 10 days more than in the reference period).

\subsection{Hydrological drought}

The main period of hydrological drought started around the latter half of July and continued until 11 November (Table 1, Fig. 6). However, unusually low discharges were already occurring from May onwards (the period March-May was marked by large discharges associated with snowmelt), which were related to low precipitation. In the main drought period, the standardised deficit volumes with respect to $Q_{330}$ at 7 hydrological stations was $>30 \%$. For the Rivers Elbe, Jizera, Morava and Svratka, the 1947 hydrological drought was one of the 3 most severe events since the late 1880s. Relatively wetter patterns in southern Bohemia, and water released from extensive fish-farming ponds, meant that water levels on the River Lužnice in 1947 were not among the 10 driest years in the same reference period; moreover, the continuous drought there lasted only to September (Table 1).

On the River Elbe at Děčín, which has the longest series of daily discharges of the 7 stations studied, as much as half of the volume was lacking compared to the long-term mean, representing 516.5 $\times 10^{6} \mathrm{~m}^{3}$ of water. The main drought period at this station lasted $117 \mathrm{~d}$ there, from 18 July to 11 November (the second longest drought period), while 161 days with drought were recorded for the whole year - the third highest (Fig. 6). In terms of annual water balance, 83 times more water than is usual were absent from Děčín, the second highest extreme since 1888.

Fig. 7 shows the distribution of the hydrological drought of 1947 for the territory of the Czech Lands expressed by standard deficiency volumes and drought duration for individual hydrological stations (Vlnas et al. 2010). Over the majority of the area, standardised deficiency volumes with respect to $Q_{95}$ were between 1 and 3, and duration of hydrological drought was $>3 \mathrm{mo}$. Some regional effects are quite pronounced, reflected in smaller deficiency volumes as well as shorter durations of drought. This is particularly so for southern Bohemia in the region extending to Plzeň, where precipitation totals for 1947 were higher than in other areas (see Fig. 4a) and rivers received discharges of water from numerous manmade fish-farming lakes. A further extended area of weaker hydrological drought is apparent in northern and northeastern Moravia, again corresponding to relatively higher precipitation totals in this area in 1947 (see Fig. 4a). Smaller areas of weaker drought 

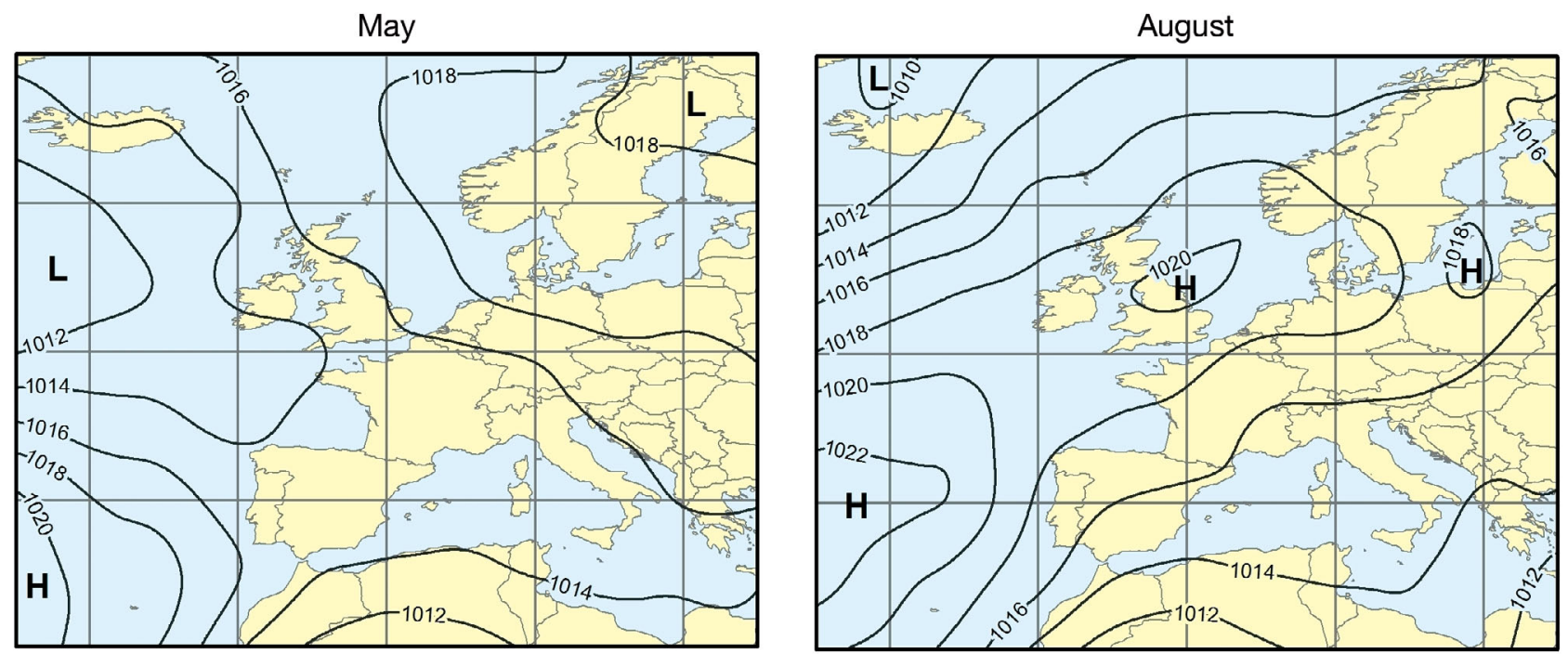

\section{September}
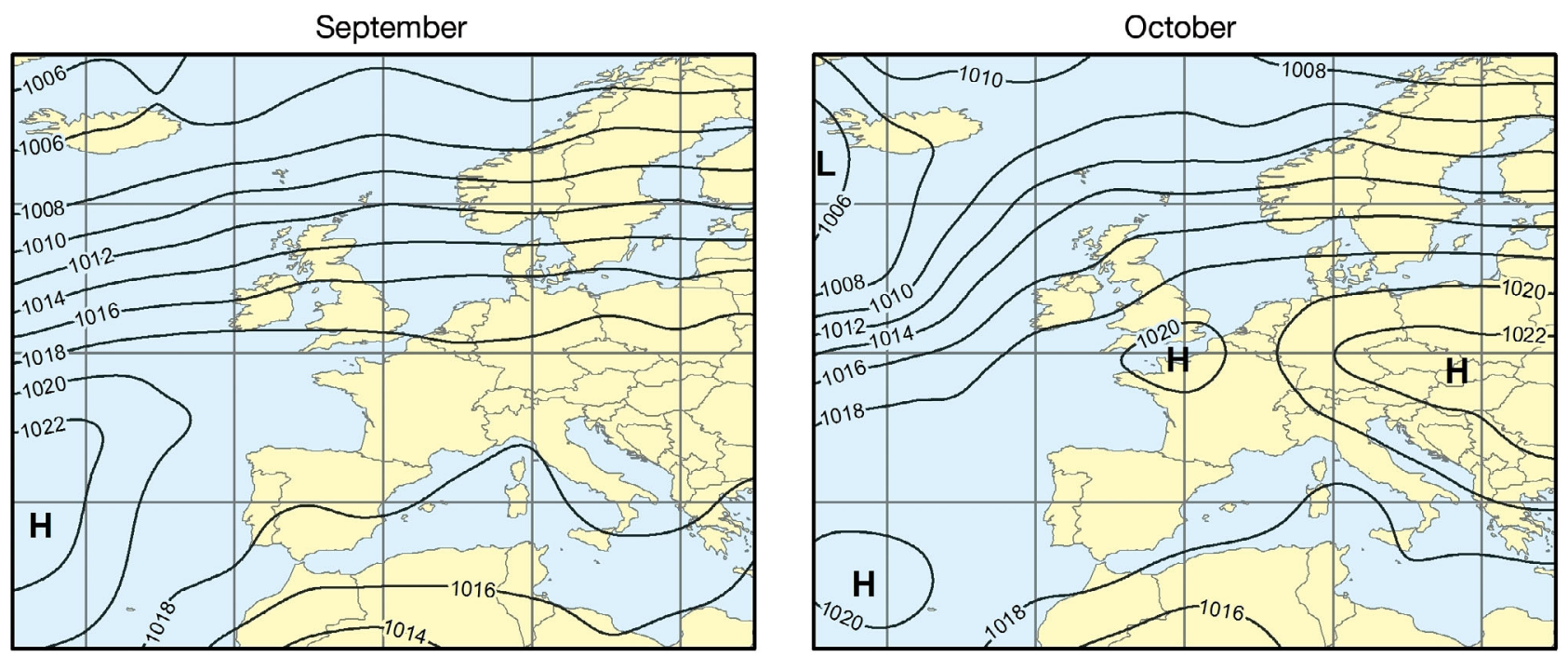

Fig. 5. Mean sea-level pressure (hPa) in the European-Atlantic area for the months of May, August, September and October 1947 when below-mean precipitation totals were recorded in the Czech Lands (adapted from Brázdil \& Trnka 2015)

also occurred in south Moravia and in the Broumov promontory, perhaps related to rain from convective storms.

\subsection{Agricultural drought}

The drought significantly influenced the course of work in the fields as well as yields of agricultural crops. Descriptions in the chronicle of the village of Jalubí, near Uherské Hradišt in Moravia, provide one example of impacts arising out of extreme drought (AS7, fol. 37v-38v):

Spring started late [...] Drought sets in. Late-sown beets did not germinate. Germination came as late as the end of May. [...] Still no rain. Catastrophe threatens. Crop remained very sparse, particularly wheat. A profusion of weeds growing. Harvest delayed due to drought. [15 June.] Still deep drought. Not raining at all, just negligible precipitation. Cattle-drawn reaping due to small, short stalks [...] Yields of the first fodder crops are very low $(30 \%)$. No green fodder crops available; they dried out after sowing. Most of the feed is [now] straw. [...] Farmers are leaving for northern Moravia to get hay there by mowing and drying. [...] Most farmers have not bedded their cattle and [thus] save the straw for feeding. Stubble-tillage of stubble fields not finished due to drought. [...] The potatoes were dug out in September, in small amounts and suffering from withered tubers. No sowing because there is [still] catastrophic drought. Beets are dug out. [Mechanical] beet-lifters breaking due to hardened soil. The 


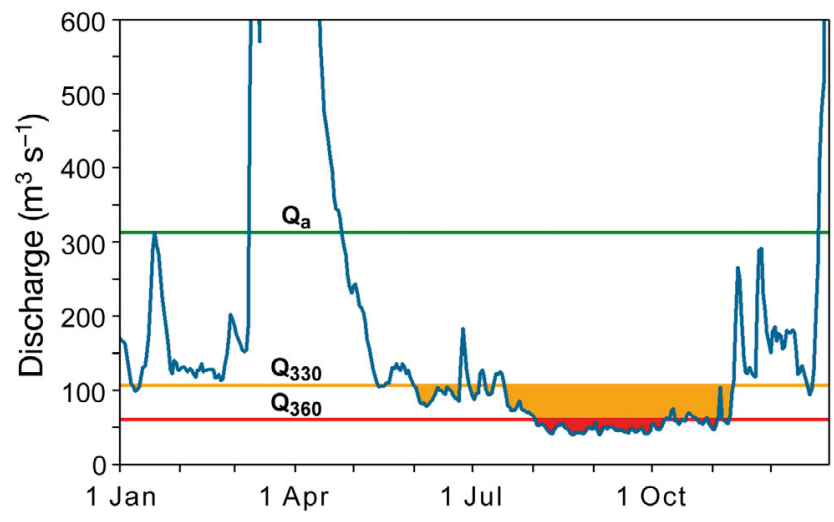

Fig. 6. Annual variation in daily discharges for the River Elbe at Děčín in 1947 showing mean annual discharge $Q_{a}$ and threshold discharges $\mathrm{Q}_{330}$ and $\mathrm{Q}_{360}$ (the discharge achieved as a mean for 360 days of the year) Orange and red areas indicate deficiency volumes in terms of $\mathrm{Q}_{330}$ and $\mathrm{Q}_{360}$ respectively

draught cattle cannot pull them. [The beet] is excavated by pickaxe. Yield of beet is below normal. [...] Fear that sowing will be impossible. [...] Dry soil is ploughed, clouds of dust during ploughing. [...] Grapes in the month of September were drying up in high temperatures and drought, and were picked early. Fruit fell from the trees and rotted heavily. [...] There was a lack of seed, particularly wheat [...] As a consequence of lack of feed, cattle and horses as well are sold off. [...] Leaves are being raked up in the for- est because of a complete shortage of straw. [...] Dried potato stalks are being used for feed.

Similar reports of failure of the harvest of the majority of agricultural crops, together with problems for plant and animal production, may be found in many other written sources.

Fig. 8 shows relative fluctuations in annual yields of selected agricultural crops for the Czech Lands in 1946-1950, expressed as percentages of yields in 1946. The data come from the Czech Statistical Office in Prague. The drought had no visible effect on barley, which was saved by precipitation in winter and early spring, nor on flax. Among the cereals, the largest drop was for wheat, $26 \%$ down on the 1946 yield, with $19 \%$ for maize for grain and $10 \%$ for rye and oats. Oil plant yields also fell off sharply, for rape by as much as $46 \%$, with this decrease continuing into 1948. Hay was particularly short, with permanent meadow yields down by $26.5 \%$ and arable soil hay by $36 \%$. There is no data for district level losses but it is reasonable to assume that the reduction in yields in some localities was much greater than at national level.

Detailed insight into regional agricultural and financial losses may be derived from reports presented to parliament by regional representatives, mainly

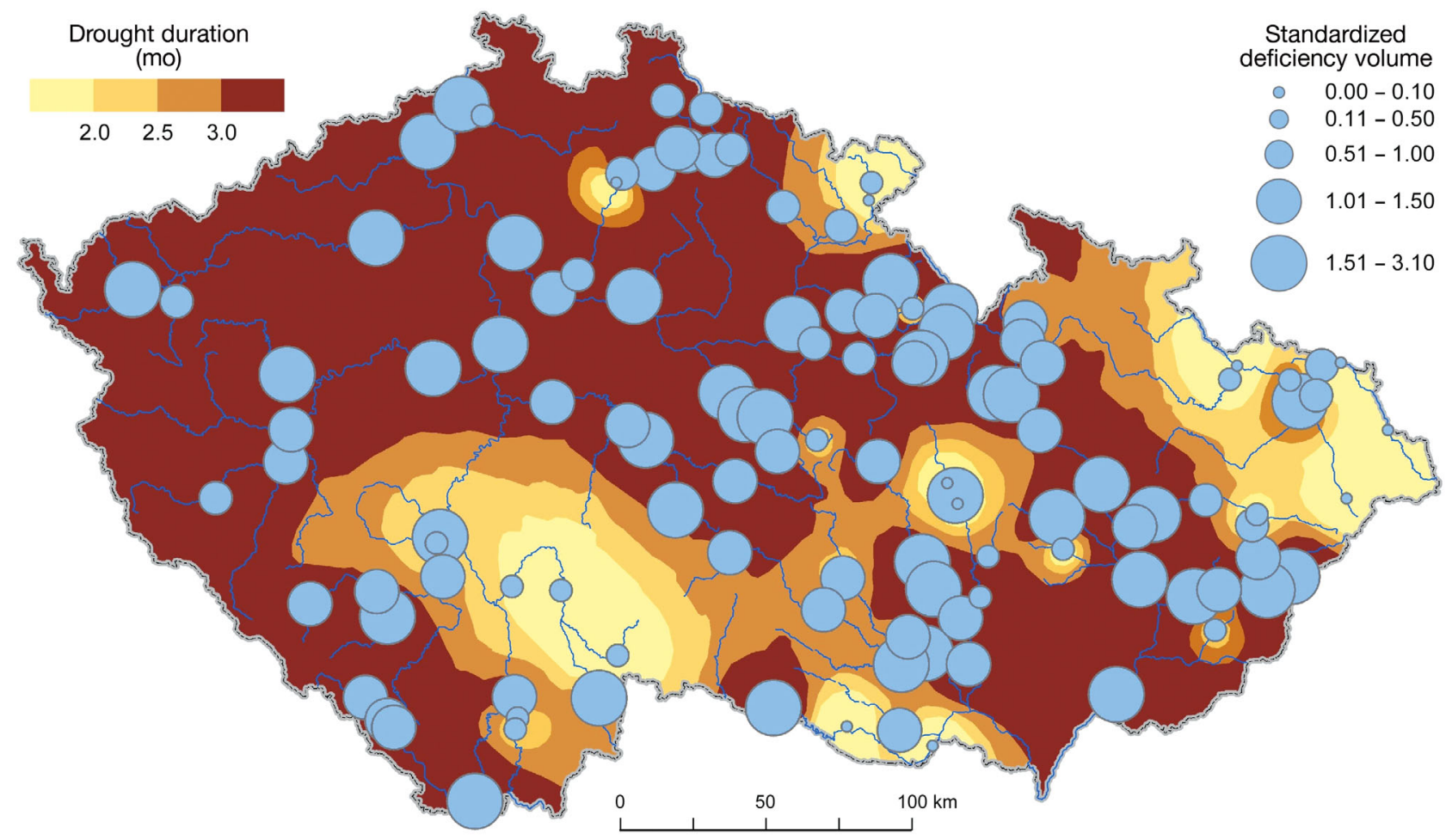

Fig. 7. Standardised deficiency volumes with respect to $Q_{95}$ (i.e. $95 \%$ of mean annual discharge) and duration of hydrological drought for the territory of the Czech Lands in 1947 (adapted from Vlnas et al. 2010) 

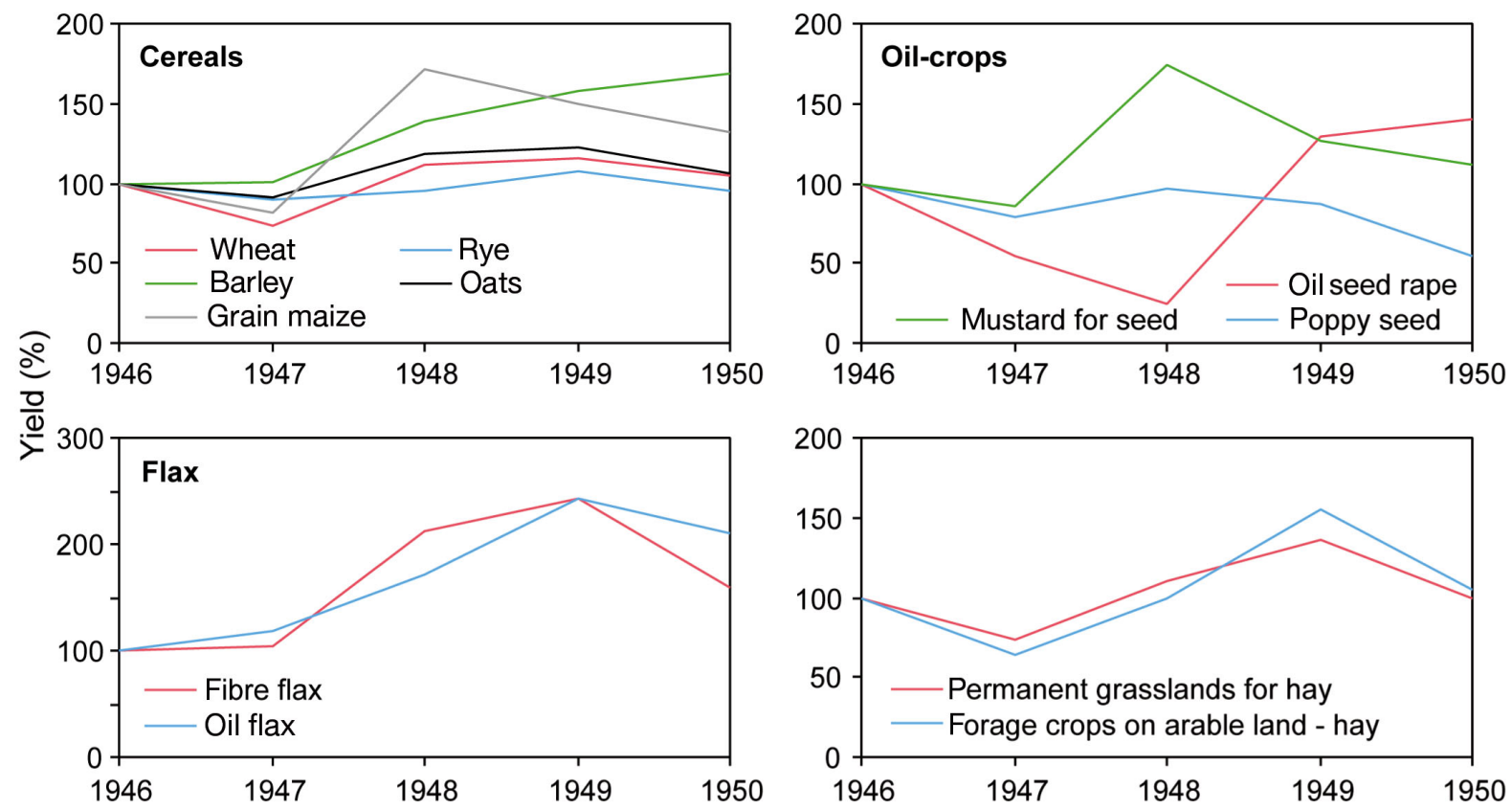

Fig. 8. Relative fluctuations in annual yields of selected agricultural crops in the Czech Lands during 1946-1950. Yields are expressed as percentages of 1946 yields $(100 \%)$

from southern and central Bohemia (Fig. 9). While statements of financial loss for some localities feature estimated values, many other cases mention only the percentage loss in relation to the previous year of 1946, and in some cases specific information is entirely missing. The reported estimated loss for 266 municipalities was 180 million Czechoslovak crowns (hereafter Kčs), giving an average of 676000 Kčs per municipality (at the time, an average worker earned around 820 crowns per month in Czechoslovakia). Two further districts together lost 234 million Kčs and there are another 88 localities and one district without indicated loss. The reported percentage loss in comparison with the previous year of 1946 was between 18 and $100 \%$. Financial losses were exacerbated by the combination of drought with other events, mainly summer hailstorms (blue hatching in Fig. 9; see also chronology in Fig. 10), pests (aphids Aphidoidea, thrips Thysanoptera and cabbage butterfly Mamestra larvae, Colorado beetle Leptinotarsa decemlineata, and viral or fungal leaf curl) and cattle disease (osteomalacia, a softening of the bones) related to lack of quality fodder. In 55 localities in southern Bohemia, reports also mention that the summer drought worsened an already critical situation caused by spring rainstorms and fungal disease ('snow mould' Monographella nivalis). Although parliamentary reports indicate a major agricultural drought in southern and central Bohemia, supple- mentary data from Rudé právo (AS6; locations in violet in Fig. 9) show that the drought significantly affected northern Bohemian districts as well.

\subsection{Immediate responses to the drought}

All over the country, the supply of agricultural products was in crisis, a situation reflected in the state administration as well as at regional and local levels. The parliamentary responses of regional representatives suggested a number of mitigation measures: (1) financial support, (2) tax write-offs, (3) releasing fixed bank deposits to enable purchase of fodder and seed, and (4) direct supply of fodder and seed. The total financial subsidy proposed by the national government was 500 million Kčs. The extent and severity of impact was thoroughly analysed, case by case, by the national statistical office both in situ and in regional administration offices. Subsidy was provided to farmers according to estimation of total losses, which had to be higher than 900 Kčs per hectare. Despite this proposal, regional representatives (mainly from the Communist Party) repeatedly made demands in late 1947 (Fig. 10) that the remaining part of the financial support (ca. 60 million Kčs) should be provided to the most affected farmers in southern Bohemia who had not obtained subsidy. However, the response to this demand, given by the 


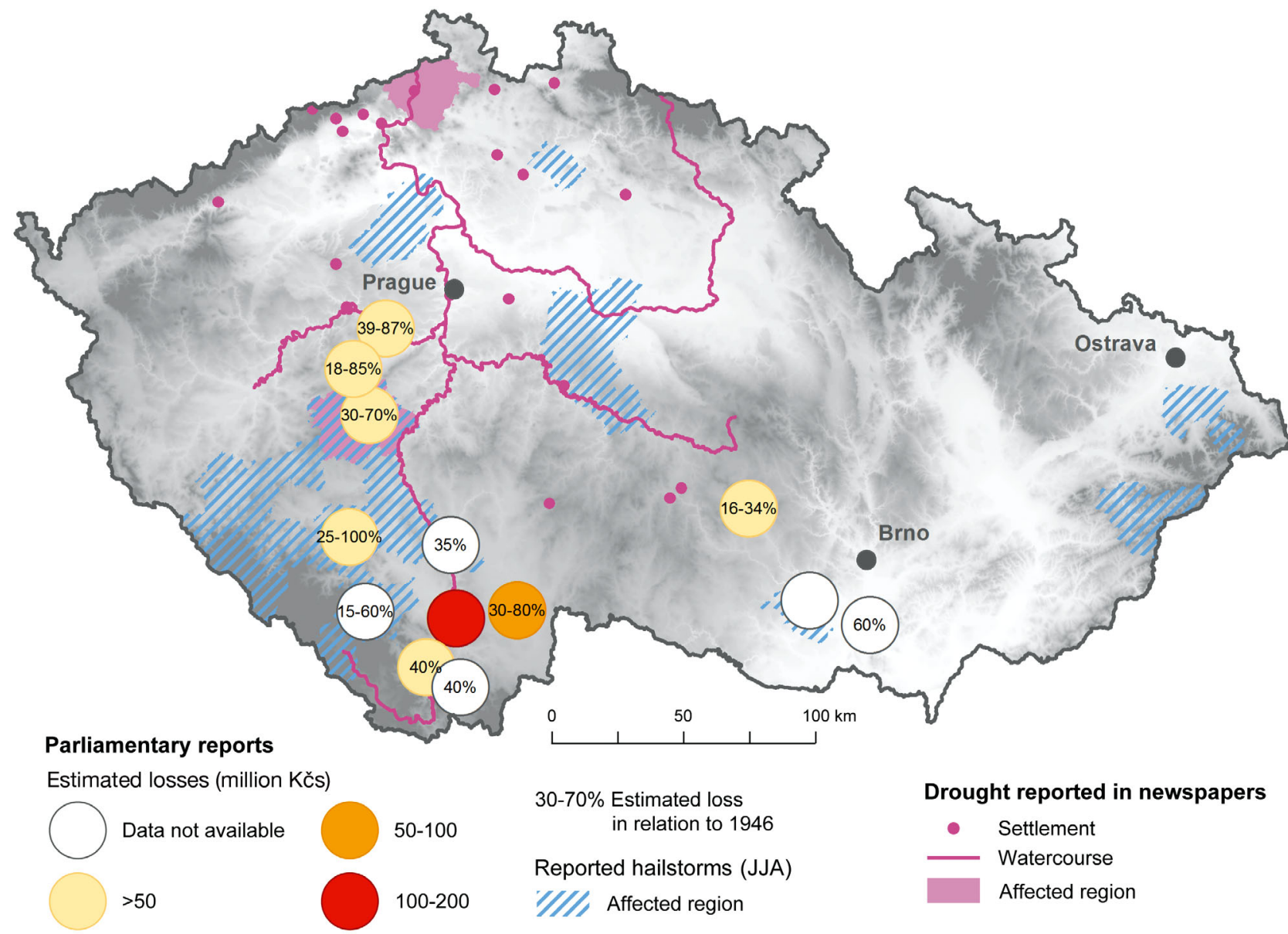

Fig. 9. Regional impacts of drought and related events from parliamentary records and other affected localities reported in Rudé právo (AS6)
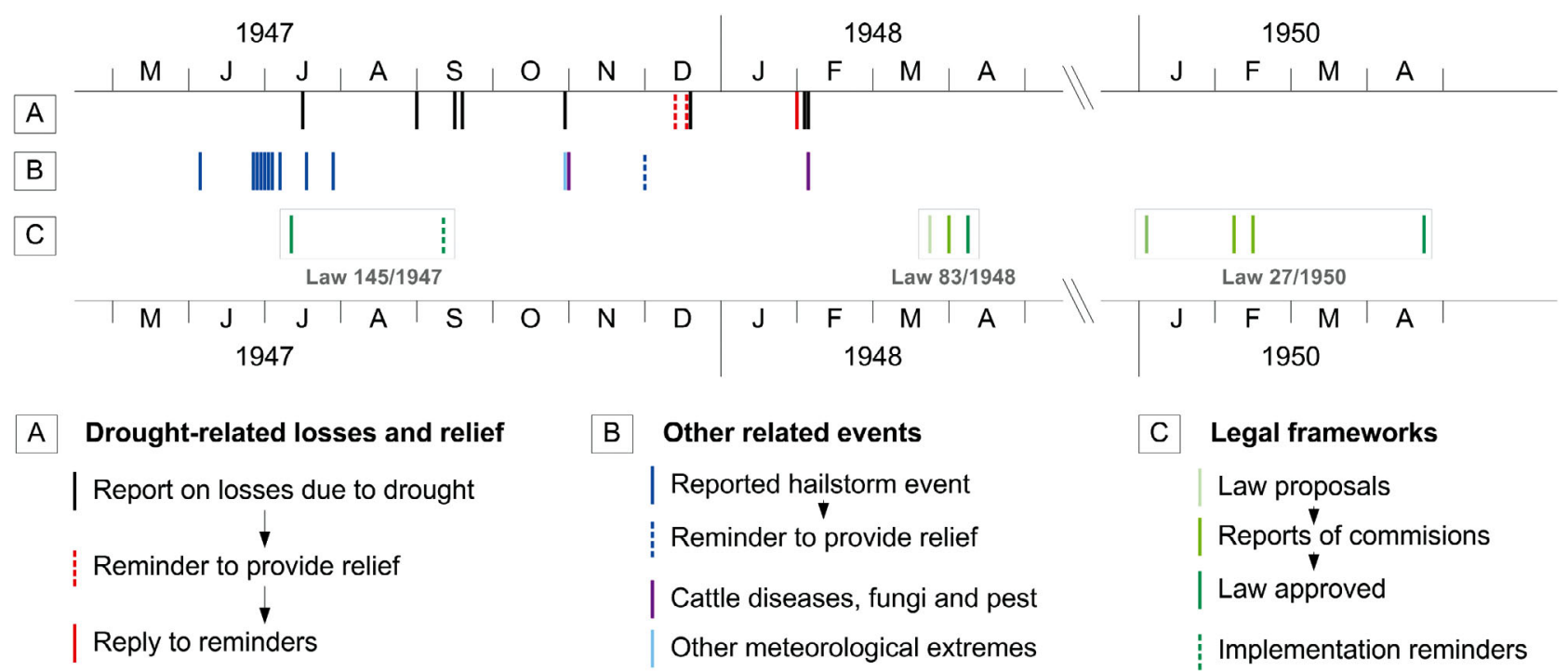
C Legal frameworks
Law proposals
Reports of commisions
| Law approved
Implementation reminders

Fig. 10. Chronology of the reports on 1947 drought in the Czech Lands and related events, and of the evolution of relevant legal frameworks 
Minister of Agriculture on 30 January 1948 noted that

the remaining part of the subsidy has already been used to increase the subsidy for 2 districts and to provide a support for another 54 Czech districts

and that

the farmers who did not obtain financial support did not meet the criterion of a loss of 900 Kčs per hectare

Of 60 million Kčs remaining from the total financial subsidy, newly-provided support to southern Bohemian districts was ca. 10 million Kčs. The constant demands and governmental responses exemplify a long-running political dispute between the Communist Party and governmental parties, framed on this occasion by the disastrous impacts of drought.

Detailed descriptive comments on drought impact mitigation are available from regional sources. Florián Gloziga, Chairman of the Extraordinary Land Commission for Nutrition, a Communist Party representative, reported the situation of supplies for the population, together with some measures taken, at a meeting of the National Moravian-Silesian Land Committee in Brno on 16 December 1947 (AS5, fol. 3r, 4r):

\begin{abstract}
An extraordinary drought and bad harvest of cereals following on from it, in our country, as in Europe and other continents, places us under an uncompromising obligation to provide the grain needed to secure the nutrition of our nation primarily from our own sources. [...] The situation that came about in this way, or rather, its perspectives, have been reflected in an avalanche of efforts [on the part] of the population to buy grain for bread, particularly wheat, by way of the black market immediately after the harvest. [...] The amount of mandatory supply was determined under these circumstances, for the Moravian-Silesian Land a total of 18500 railway cars, 6938 of which were wheat and 11562 rye.
\end{abstract}

However, as of 15 December, only $54 \%$ of the wheat, $73 \%$ of the rye, and $45 \%$ of the feed grain (but $102 \%$ of the barley) from the mandated quantities of cereals had been supplied. Thus, despite these measures, it was clear that Czechoslovakia was in need of international help. Leading politicians saw a remedy for the lack of grain in help from the Soviet Union, as further reported by Florián Gloziga (AS5, fol. $5 r-6 r)$ :

[...] for supply and provision of grain for bread from abroad, apart from smaller amounts from Canada, Yugoslavia and Bulgaria, given the present-day international situation - realistically considered - whatever purchase was and is beyond our means. [...] Further, the great merit of our Soviet ally should be appreciated for basic help with our nutrition plan realised in July 1947 by the Czechoslovak delegation headed by Prime Minister Klement Gottwald in Moscow, when the supply of grain for bread and animal feed for our state was negotiated [...] The Soviet government and its premier 'Generalissimus' Stalin in person [...] guaranteed a supply of 200,000 tons of wheat and 200,000 tons of grain for feed. [...] In summer it was not yet possible determine the exact extent of crop failure. The consequences of the drought made it clear that in autumn [matters were] far worse and acute supply problems threatened Czechoslovakia [...] In this situation, on 25 November of this year Prime Minister Gottwald turned to USSR premier 'Gen.' Stalin with a personal letter [...] and requested whether, among other things, it would be possible to increase the supply of Soviet grain by at least around 150,000 tons. 'Gen.' Stalin's telegraphed reply of 29 November informed [us] that, after consultation with the relevant Soviet officials, Czechoslovakia is offered not 150, 000 tons, but 200,000 tons of grain for bread over and above the amount that was agreed in summer. [...] Thus the Soviet Union will provide us a total of 600,000 tons of grain from the 1947 harvest, 400,000 tons of it for bread, i.e. wheat and rye, and 200,000 tons of feed grain. Of this, 50,000 tons of grain for bread and 50,000 tons of feed grain will be supplied by the end of this year, the remainder progressively to the end of April 1948.

The catastrophic impacts of the 1947 drought also led to new approaches to legal frameworks for support during and after disasters. Since 1927, when an act came into law as a consequence of disastrous flash floods (Raška \& Brázdil 2015), subsidies to agriculture had been provided from a fund set up for this purpose. The funds were progressively subsidised, but the financial amounts were not sufficient to cover the impacts of high-magnitude events, the scheme lacked supportive tools to provide relief and the scope of fund management authority was unclear. The similar situation was clearly described in a statement to parliament on 11 September 1947:

According to Act No. 145/1947 [AS2] on the organization of Czechoslovak agriculture, the farmers' unions are obliged to support those affected by natural extremes $[\ldots]$

This was done from regional funds, e.g.

The disaster fund in Brno established in 1939 [...] which received by 9.5 million Kčs annually in donations.

However, the extent of the regions affected by drought exceeded the original scope of the fund. Parliamentary representatives therefore called for an increase in governmental subsidies to the fund and suggested supportive measures for provision of financial relief. The government resolution from 2 September on an extraordinary surcharge on purchase prices 
and on payment of extraordinary support was the first legislative response to the 1947 drought (cf. Fig. 10).

In April 1948, Act 83/1948 (AS3) on a fund for mitigation of impacts arising out of the extreme drought of 1947 was approved. The act resolved some of the former problems associated with disaster funds (see above) and defined the financial sources, in accord with communist policies, as: (1) extraordinary charges for 'excessive property', (2) a luxury tax, and (3) other special arrangements. Moreover, it defined the areas of financial subsidy that should now cover: (1) extraordinary surcharges on purchase prices of agricultural products, (2) expenses for transport of extraordinary subsidies of fodder, (3) expenses for pest control (Colorado beetle Leptinotarsa decemlineata), (4) additional expenses arising from the differences between foreign and domestic prices (i.e. reduction of prices of imported products to ensure their availability to local farmers), (5) a financial subsidy to farmers of up to 500 million Kčs (see above), (6) compensation to farmers who had not contributed to prescribed contingency funds (up to 12 million Kčs), (7) obligations related to loans, and (8) losses arising out of cattle deaths (up to 30 million Kčs). The financial subsidy had to be applied for by the end of 1948 .

\section{DISCUSSION}

\subsection{Spatial and temporal context of 1947 drought}

That the 1947 drought in the Czech Lands was very severe follows from analysis of the entire period of instrumental meteorological observations, i.e. 18042014. The drought episode from April to October 1947 was evaluated as the most extreme meteorological drought event according to SPEI-1 and Z-index (followed by April-October droughts in 1868 and 1834 for both indices). According to precipitation-based SPI-1, April-October 1947 was the most extreme drought in the period, together with that of 1842 (for a detailed overview of all severe droughts in the Czech Lands, see Brázdil \& Trnka 2015).

The hydrological drought of 1947, considered in terms of daily discharge, i.e. duration and deficiency volume of water, was one of the 3 most important drought events since the late 1880s (together with 1904, 1911 and 1921). Where precipitation totals were higher, or certain anthropogenic interventions were in play, the drought was far less extreme. The spatial distribution of the hydrological drought over the territory of the Czech Lands (Fig. 7), based on characteristics calculated from monthly discharges, tallies well with the distribution of April-October precipitation totals (Fig. 4a).

A large number of publications have addressed the drought of 1947 in the territories surrounding the Czech Lands. Lauscher (1948) analysed temperatures and precipitation for 1947 in Austria, drawing particular attention to the long period of above-mean temperatures from April to September (particularly September) and low precipitation totals in the growing season, around only 50 to $60 \%$ of the long-term mean. September and October were the driest, while all the months from April to October were below mean. A similar situation was described for Switzerland by Bider (1948), making partial use of the data from long-term series for Basle and further data from around the country. He even compared the warm and dry patterns of 1947 with those of 1540 , to which more recently - based on extensive European documentary data - the term 'megadrought' has been applied (Wetter et al. 2014). More detailed analysis of the 1947 drought in Switzerland was contributed later by Schorer (1992) and Widmer (2003). Petrovič (1948) reported on the catastrophic drought of 1947 with particular reference to southern and central Slovakia. Based on data from the Hurbanovo station, he found this to have been the most severe drought since the beginning of observations in 1871 (for example, the dry period from 25 July to 17 October was almost without rain, except for a few showers with totals below $1 \mathrm{~mm}$ ). He attributed the 1947 drought to highpressure conditions and the absence of cyclones from the south. There is similarly rich information from Germany (e.g. Geiger 1948, 1951, DWD 1941). In Poland, Mager et al. (2000) considered the country's 171 days with low river flow in 1947 the eighth most severe hydrological drought in the 1901-1995 period; $87 \%$ of the area of Poland experienced 'atmospheric' drought, ranking 1947 equal fifth with 1921 for the 1891-1995 period. The last significant locust invasion was recorded in Hungary in 1947 (Kiss 2012). These reports from a number of countries confirm that the 1947 drought was a significant Central European climate anomaly. Moreover, Briffa et al. (1994) classified summer 1947 as the driest in terms of mean PDSI and spatial extent of moderate drought (PDSI <-2) over Europe for the 1892-1991 period. As indicated in Fig. 11a, April-October 1947 in Europe was very warm in a broad belt extending from the Iberian Peninsula over Central Europe to Turkey, while below-mean precipitation totals also prevailed in the greater part of this belt (Fig. 11b). That PDSI values showed dry patterns over the major part of Europe is hardly surprising (Fig. 11c). 

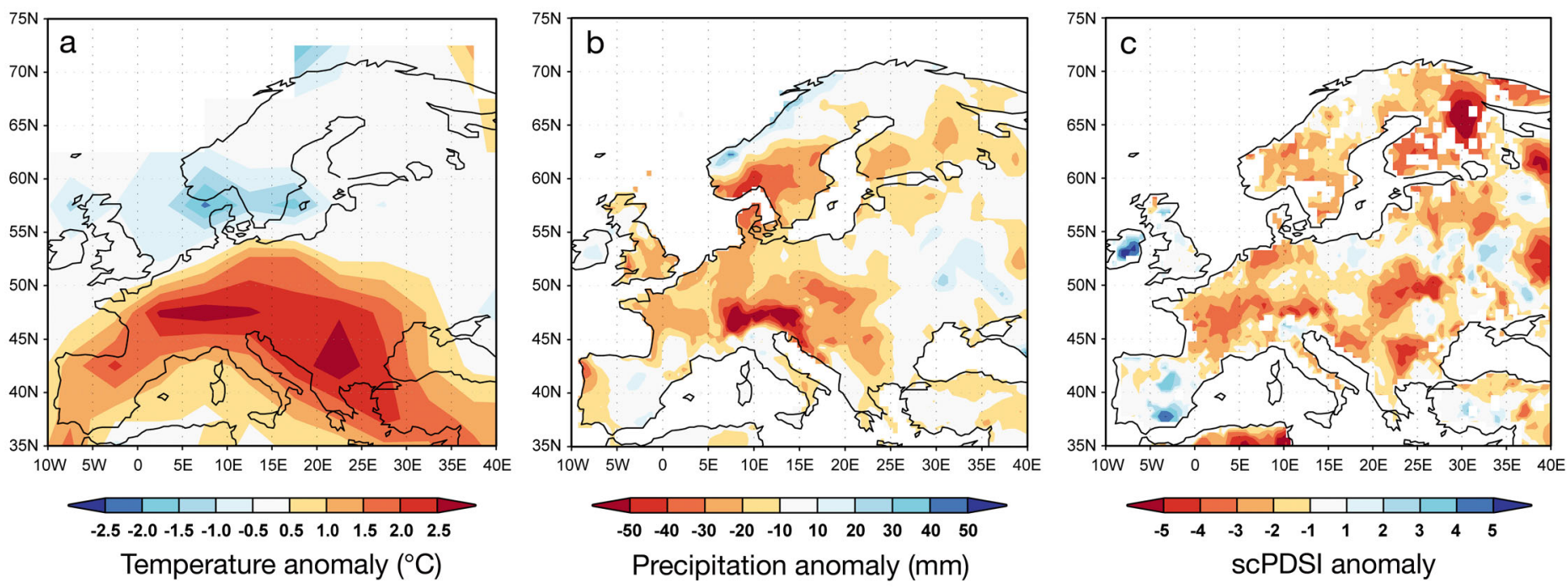

Fig. 11. April-October 1947 anomalies of (a) air temperatures (HadCTRU4 database, Morice et al. 2012), (b) precipitation totals (CRU TS3.23 database, Jones \& Harris 2008), (c) self-calibrating Palmer Drought Severity Index (PDSI) (CRU self-calibrating PDSI 3.21, van der Schrier et al. 2006) in Europe, compared to the 1961-1990 reference period

\subsection{Impacts of the 1947 drought}

Consideration of the agricultural impacts of the 1947 drought must take into account that it was preceded by a particularly cold January and February, in which heavy frosts (Figs. 2 \& 3) affected winter crops. Part of the areas originally sown with winter cereals had to be re-ploughed and sown again, or were not harvested. This situation is comparable to the winter of 2002-2003 (Trnka et al. 2010) and its subsequent severe drought (Ciais et al. 2005). This left the agricultural sector particularly exposed to drought in the April-June period, as winter crops are less sensitive to drought in these months (Hlavinka et al. 2009). The decrease of acreage of all crops from 1946 to 1947 is consistent with severe damage, since it made no financial sense to harvest at all. The sheer duration of the 1947 drought, from April to October, is a further unusual characteristic, meaning that later-maturing crops (e.g. potatoes, beet, sugar beet, forage crops) were severely affected. If drought occurs early in the season (April-June), the early-maturing crops (e.g. barley, wheat, oilseed rape) suffer, as was the case in 2000 and 2012. If drought occurs later (July-September), it affects later-maturing crops (e.g. maize, potatoes, beet, sugar beet, hay) as occurred in 2003 and 2015. The later-maturing crops are able, in the course of their crop calendar and with a longer growing season, to compensate to a certain extent for drought early in the season
(Hlavinka et al. 2009). As droughts only rarely occur throughout the whole vegetation season, the agricultural sector production as a whole is usually fairly stable.

The exceptional losses in 1947 were partly due to the fact that extreme drought, to a varying extent and in certain regions (Figs. 3 \& 4), persisted throughout sensitive periods for all the major crops. Drops in agricultural production appeared in many European areas. As pointed out by Schorer (1992), FAO data shows that the national yields of wheat were lower in 1947 than 1942-1949 yields all over Europe; falls in production reached $36.3 \%$ in Belgium, $33.8 \%$ in France, $32.5 \%$ in Czechoslovakia, $31.0 \%$ in Finland, $29.7 \%$ in Denmark, $27.6 \%$ in Hungary, and $27.1 \%$ in Germany, to mention only a few. The deepest drops in potato production were recorded in Czechoslovakia (24.3\%), Great Britain $(15.0 \%)$ and Germany $(14.6 \%)$. This demonstrates that the territory then known as Czechoslovakia was particularly affected.

Drought impacts in 1947 were not confined to agriculture. For example, Bider (1948) reports lack of water in some towns, navigation restriction on the River Rhine and reduced electricity capacity in Switzerland. Geiger (1951) reported that 1.4 million $\mathrm{m}^{3}$ of timber was felled in Bavaria as a direct consequence of the 1947 drought. The final damage to forestry was even more severe, because this number could not include trees damaged by the bark beetles that prospered in drought-weakened forests. 


\subsection{Political factors and additional responses to catastrophic drought}

The disastrous drought of 1947 and the associated dramatic failure of the harvest struck in the immediate post-Second World War period, when the political situation was in a state of flux. The UNRRA (United Nations Relief and Rehabilitation Administration) programme ended in summer 1947, and the newlyoffered Marshall Plan (European Recovery Program) was rejected by the Czechoslovak government on 10 July 1947 (Michálek 2007). The 'Soviet grain aid' (Section 3.4) to Czechoslovakia came at a time of great famine in the Soviet Union (1946-1948, with 1947 as core year) for which Ellman (2000) reports excess mortality in the range of 1.0 to 1.5 million people (see also Volkov 1992 for details). This was a consequence of bad harvests caused by drought and of reduced food availability. He argues that the surplus stocks held by the state would probably have been sufficient to save all the people who died of starvation, but the priorities of the Soviet government lay elsewhere. The 'brotherly help' for Czechoslovakia may have been one of them, aimed at consolidating the Soviet hold on the Central European region and diminishing US influence there. This aid became an effective propaganda tool for the Communist Party, which finally swept to power in Czechoslovakia in early 1948. After that, such Soviet aid held a special place in the public memory for decades, and was even reflected in the historiography of Czechoslovakia (e.g. Husa 1961).

Legal frameworks, too, altered in response to the drought. Experience with fund-based disaster relief during the 1947 event exposed significant shortcomings in previous approaches and finally led to the proposal of a new system, defined by Act 27/1950 (AS1) on state support during natural disasters. The new act ended the fund-based principle of disaster relief and defined the sources, types of subsidies (finance, goods and other), aims, eligibility of recipients and controlling mechanisms for subsidies. This law remained valid until a new act was passed subsequent to the disastrous flood of 2002 in the Czech Republic (Brázdil et al. 2005).

At a regional and local level, the 1947 drought resulted in reconsideration of the landscape-ecological measures associated with territorial planning. General policies of the time were based on 2 major principles: centralisation in the interests of economic production, and the transformation of nature by means of technological progress, intended to optimise production and profits. Both these principles had emerged from communist ideology and strategies in the Soviet Union, where Stalin's 'Great Plan for the Transformation of Nature' was approved on 20 October 1948 (Brain 2010).

An example of landscape planning responses to the 1947 drought in the Czech Lands may be found in action taken in southern Moravia. The land committee approved a plan to create a system of windbreaks in order to protect fields from wind erosion (Šanovec 1948). More than 300 ha of windbreaks were planted during 1948-1952 and ca. 1100 ha by 1960, when the windbreak strategy for land amelioration gave way to the construction of large water reservoirs (Orsillo 2015)

\section{CONCLUSIONS}

The 1947 drought episode in the Czech Lands through its physical nature and severity and particularly in its economic and social-political impacts, responses and consequences - holds an exceptional position among all the severe drought events from the 19th century to the present time. No other episode motivated researchers and administrations to such broad responses, or occupied a place in public memory for such a long time. The exceptional nature of the 1947 drought was accentuated by the fact that it came at the time of post-war renewal in the country, when the economy was still destabilised. Further, it was followed by more relatively dry years from 1948 to 1954. The authors consider this study a necessary, truly objective and independent evaluation of impacts of 1947, which was impossible prior to the profound change of the country's political direction in 1989. Moreover, information about the 1947 drought and its impacts in other European countries shows that it was an important climate anomaly of great territorial extent with significant socioeconomic impacts, well worthy of detailed study on a broader European scale.

The disastrous drought of 1947 may be also put into the context of increasing dryness observed in the Czech Republic in the course of recent decades, particularly after the year 2000 (Brázdil \& Trnka 2015). Moreover, existing climate change projections with multiple GCMs indicate an increased risk of drought events in the Central European region (e.g. Dai 2013, Dubrovsky et al. 2015) as well as increased likelihood of drought occurrence during critical periods for agricultural crops (e.g. Trnka et al. 2014, 2015). This means that droughts of the '1947 type' may occur even more frequently in the 21st century, with the 
disastrous impacts on agriculture, water management, forestry and other sectors of the national economy that became all too evident in that year.

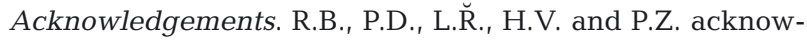
ledge support of the Grant Agency of the Czech Republic for project no. 13-19831S and P.R. for project no. 13-02080P. M.T. acknowledges support from the Ministry of Education, Youth and Sports of the Czech Republic within the National Sustainability Program I (NPU I), grant no. LO1415 and grant LD13030. Christian Pfister (Bern) is acknowledged for the reference to Swiss papers for 1947 drought. Tony Long (Svinošice) improved the English.

\section{LITERATURE CITED}

Allan RJ, Ansell TJ (2006) A new globally complete monthly historical mean sea level pressure data set (HadSLP2): 1850-2004. J Clim 19:5816-5842

Bider M (1948) Meteorologische Betrachtung zum Sommer 1947. Leben und Umwelt 4:111-116

Brádka J (1972) Srážky na území ČSSR při jednotlivých typech povětrnostní situace (Precipitation on the territory of the CSSR in particular types of weather situation). Sborník prací Hydrometeorologického ústavu v Praze 18: 8-62

Brádka J, Dřevikovský A, Gregor Z, Kolesár J (1961) Počasí na území Čech a Moravy v typických povětrnostních situacích (Weather over the territory of Bohemia and Moravia in typical weather situations). Hydrometeorologický ústav, Praha

Brain S (2010) The great Stalin plan for the transformation of nature. Environ Hist 15:670-700

Brázdil R, Trnka M (eds) (2015) Sucho v českých zemích: minulost, současnost, budoucnost (Drought in the Czech Lands: past, present, future). Centrum výzkumu globální změny Akademie věd České republiky, v.v.i., Brno

Brázdil R, Dobrovolný P, Elleder L, Kakos V and others (2005) Historické a současné povodně v České republice (Historical and recent floods in the Czech Republic). Masarykova univerzita, Český hydrometeorologický ústav, Brno, Praha

Brázdil R, Trnka M, Dobrovolný P, Chromá K, Hlavinka P, Žalud Z (2009) Variability of droughts in the Czech Republic, 1881-2006. Theor Appl Climatol 97:297-315

Brázdil R, Zahradníček P, Pišoft P, Štěpánek P, Bělínová M, Dobrovolný P (2012) Temperature and precipitation fluctuations in the Czech Lands during the period of instrumental measurements. Theor Appl Climatol 110:17-34

Brázdil R, Dobrovolný P, Trnka M, Kotyza O and others (2013) Droughts in the Czech Lands, 1090-2012 AD. Clim Past 9:1985-2002

Briffa KR, Jones PD, Hulme M (1994) Summer moisture variability across Europe, 1892-1991: an analysis based on the Palmer Drought Severity Index. Int J Climatol 14: 475-506

> Ciais P, Reichstein M, Viovy N, Granier A and others (2005) Europe-wide reduction in primary productivity caused by the heat and drought in 2003. Nature 437:529-533

> Dai A (2013) Increasing drought under global warming in observations and models. Nat Clim Change 3:52-58

- Dubrovsky M, Trnka M, Holman IP, Svobodova E, Harrison
PA (2015) Developing a reduced-form ensemble of climate change scenarios for Europe and its application to selected impact indicators. Clim Change 128:169-186

DWD (Deutscher Wetterdienst) (1949) Der heiße und trockene Sommer 1947. Berichte des Deutschen Wetterdienstes in der US-Zone 7, Bad Kissingen

> Ellman M (2000) The 1947 Soviet famine and the entitlement approach to famines. Camb J Econ 24:603-630

Geiger R (1948) Die Auswirkungen der Dürre (Dürrezahlen und Dürrewirkungzahlen). Meteorol Rundsch 1:513-516

Geiger R (1951) Die Waldgefährdung durch den Dürresommer 1947. Forstwissenschaftliches Centralblatt 70: 349-355

Heim RR (2002) A review of twentieth-century drought indices used in the United States. Bull Am Meteorol Soc 83:1149-1165

Hisdal H, Tallaksen LM (eds) (2000) Drought event definition. Technical report to the ARIDE Project No. 6. Department of Geophysics, University of Oslo

> Hlavinka P, Trnka M, Semerádová D, Dubrovský M, Žalud Z, Možný M (2009) Effect of drought on yield variability of key crops in Czech Republic. Agric For Meteorol 149: 431-442

- Hoerling M, Eischeid J, Kumar A, Leung R and others (2014) Causes and predictability of the 2012 Great Plains drought. Bull Am Meteorol Soc 95:269-282

Husa V (1961) Dějiny Československa: k 40. výročí založení KSČ (History of Czechoslovakia: for the 40th anniversary of the Czechoslovak Communist Party). Orbis, Praha

Jones PD, Harris I (2008) Climatic Research Unit (CRU) time-series datasets of variations in climate with variations in other phenomena. NCAS British Atmospheric Data Centre, http://catalogue.ceda.ac.uk/uuid/3f89448 00cc48e1cbc29a5ee12d8542d (accessed 12 Oct 2015)

Juneja M, Mauelshagen F (2007) Disasters and pre-industrial societies; historiographic trends and comparative perspectives. Mediev Hist J 10:1-31

Kiss A (2012) A sáskajárások néhány területi és tájtörténeti vonatkozása a Kárpát-medencében (Some regional and areal consequences of historical locust invasions in the Carpathian Basin). In: Füleky G (ed) A táj változásai a Kárpát-medencében. Történeti emlékek a tájban. Szent István Egyetem, Gödöllö, p 123-132

> Kyselý J (2002) Temporal fluctuations in heat waves at Prague-Klementinum, the Czech Republic, from 190197 , and their relationships to atmospheric circulation. Int J Climatol 22:33-50

Lauscher F (1948) Das abnormale Witterungsjahr 1947. Wetter und Leben 1:1-6

Mager P, Kuźnicka M, Kępińska-Kasprzak M, Farat R (2000) Change in the intensity and frequency of occurrence of droughts in Poland (1891-1995). Geogr Pol 73:41-47

> McCombs M, Shaw D (1972) The agenda-setting function of mass media. Public Opin Q 36:176-184

McKee TB, Doesken NJ, Kleist J (1993) The relationship of drought frequency and duration to time steps. In: Preprints, 8th Conference on Applied Climatology, Anaheim, CA, 17-22 January 1993. American Meteorological Society, Boston, MA, 179-184

Michálek S (2007) Odmítnutí Marshallova plánu. Československá politika mezi Východem a Západem (Rejection of the Marshall Plan. Czechoslovak politics between East and West). Dějiny a současnost 29:33-36

Mishra AK, Singh VP (2010) A review of drought concepts. J Hydrol (Amst) 391:202-216 
Morice CP, Kennedy JJ, Rayner NA, Jones PD (2012) Quantifying uncertainties in global and regional temperature change using an ensemble of observational estimates: the HadCRUT4 dataset. J Geophys Res 117:D08101

Munich Re (2015) Topics Geo. Natural catastrophes 2014. Analyses, assessments, positions. Münchener Rückversicherungs-Gesellschaft, München

Orsillo N (2015) Zmírnit pohyb vzdušných proudů ... (To reduce the movement of air flows ...). Dějiny a současnost 2:22-25

Palmer WC (1965) Meteorological drought. Office of Climatology Research Paper 45. US Weather Bureau, Washington, DC

Petrovič Š (1948) Sucho roku 1947 (The drought of 1947). Slovenské pol'nohospodárstvo 3:58-62

Pfister C (2009) Learning from natural-induced disasters: theoretical considerations and case studies from Western Europe. In: Mauch C, Pfister C (eds) Natural disasters, cultural responses. Lexington Books, Plymouth, p 17-40

Poliwoda G (2007) Learning from disasters: Saxony fights the floods of the river Elbe 1784-1845. Hist Soc Res (Koln) 32:169-199

Raška P, Brázdil R (2015) Participatory responses to historical flash floods and their relevance for current risk reduction: a view from a post-communist country. Area 47:166-178

Raška P, Zábranský V, Dubišar J, Kadlec A, Hrbáčová A, Strnad T (2014) Documentary proxies and interdisciplinary research on historic geomorphologic hazards: a discussion of the current state from a central European perspective. Nat Hazards 70:705-732

Šanovec J (1948) Větrolamy, nový způsob meliorace pozemků (Windbreaks, a new method of land amelioration). Brázda, Praha

Schenk GJ (2007) Historical disaster research: state of research, concepts, methods and case studies. Hist Soc Res (Koln) 32:9-31

Schorer M (1992) Extreme Trockensommer in der Schweiz und ihre Folgen für Natur und Wirtschaft. In: Geographica Bernensia, G40. Geographisches Institut der Universität Bern, Bern

Šercl P, Lett P (2002) Výpočet rastru srážek v prostředí GIS (s využitím ArcView Spatial Analyst). Uživatelská př́ručka verze 2.0.1. (Calculation of precipitation grid in the GIS [using ArcView Spatial Analyst]. User Guide Version 2.0.1). ČHMÚ, OPV, Praha

Stanford M (1986) The nature of historical knowledge. Blackwell, Oxford

Štěpánek P, Zahradníček P, Brázdil R, Tolasz R (2011) Metodologie kontroly a homogenizace časových řad $\mathrm{V}$ klimatologii (Methodology of data quality control and homogenisation of time series in climatology). Český hydrometeorologický ústav, Praha
Štěpánek P, Zahradníček P, Farda A (2013) Experiences with data quality control and homogenization of daily records of various meteorological elements in the Czech Republic in the period 1961-2010. Időjárás 117:123-141

Tallaksen LM, van Lanen HAJ (eds) (2004) Hydrological drought: processes and estimation methods for streamflow and groundwater. Developments in water science 48. Elsevier, Amsterdam

Trenberth KE, Fasullo JT (2012) Climate extremes and climate change: The Russian heat wave and other climate extremes of 2010. J Geophys Res 117:D17103

Trnka M, Dubrovský M, Svoboda M, Semerádová D, Hayes M, Žalud Z, Wilhite D (2009) Developing a regional drought climatology for the Czech Republic. Int J Climatol 29:863-883

Trnka M, Kocmánková E, Balek J, Eitzinger J and others (2010) Simple snow cover model for agrometeorological applications. Agric For Meteorol 150:1115-1127

Trnka M, Rötter RP, Ruiz-Ramos M, Kersebaum KC, Olesen JE, Žalud Z, Semenov MA (2014) Adverse weather conditions for European wheat production will become more frequent with climate change. Nat Clim Change 4: $637-643$

Trnka M, Hlavinka P, Semenov M (2015) Adaptation options for wheat in Europe will be limited by increased adverse weather events under climate change. J R Soc Interface 12:20150721

> van der Schrier G, Briffa KR, Jones PD, Osborn TJ (2006) Summer moisture variability across Europe. J Clim 19: 2818-2834

Vicente-Serrano SM, Beguería S, López-Moreno JI (2010) A multi-scalar drought index sensitive to global warming: the Standardized Precipitation Evapotranspiration Index. J Clim 23:1696-1718

Vlnas R, Novický O, Kašpárek L, Hanslík E and others (2010) Časová a plošná variabilita hydrologického sucha v podmínkách klimatické změny na území České republiky (Temporal and spatial variability of hydrological drought in conditions of climate change over the territory of the Czech Republic). Výzkumný ústav vodohospodářský T. G. Masaryka, v.v.i., Praha

Volkov IM (1992) The drought and famine of 1946-47. Russ Stud Hist 31:31-60

Voss M, Wagner K (2010) Learning from (small) disasters. Nat Hazards 55:657-669

> Wetter O, Pfister C, Werner JP, Zorita E and others (2014) The year-long unprecedented European heat and drought of $154-\mathrm{a}$ worst case. Clim Change 125: 349-363

Widmer M (2003) Die Trockenheit von 1947: der extreme Trockensommer von 1947 in seiner Wirkung auf das sozio-ökonomische System der Schweiz. Lizentiatsarbeit, Historisches Institut der Universität Bern 
Appendix. Archival sources

(AS1) Act 27/1950. Zákon o státní podpoře při živelních pohromách (Act 27/1947 on state support during natural disasters)

(AS2) Act 145/1947. Zákon o organisaci zemědělců republiky Československé (Act 145/1947 on the organization of Czechoslovak agriculture)

(AS3) Act 83/1948. Zákon o zř́zení fondu pro zmírnění škod způsobených mimořádným suchem v roce 1947 v oboru zemědělství a výživy (Act 83/1948 on a fund for mitigation of impacts on agriculture and food provision arising out of the extreme drought of 1947)

(AS4) Digital parliamentary repository of the Czech Republic. Available at www.psp.cz/eknih/index.htm (accessed 30 Sep 2015)

(AS5) Moravský zemský archiv Brno, fond B 280 Zemský národní výbor Brno, Volené orgány a sekretariát, 1945-1948, inv. č. 12 Zápisy z 12. schůze pléna ZNR, orig., 16-19/12, 1947

(AS6) Rudé právo newspaper, year 1947. National Library of the Czech Republic, Prague

(AS7) Státní okresní archiv Uherské Hradiště, fond MNV Jalubí, I: Kronika obce Jalubí, 1. svazek 1924-1947

Editorial responsibility: Ulf B ntgen (Guest Editor), Birmensdorf, Switzerland
Submitted: November 3, 2015; Accepted: March 2, 2016

Proofs received from author(s): June 2, 2016 